\title{
Ocular causes of visual distortions
}

Corey J Rowland, Lawrence R Lee

\section{Background}

Patients with complaints of visual distortions may first present to their general practitioners (GPs) for assessment. Visual distortions can present in various forms, from blurred images to aberrations of colour. It is important to clarify any complaints of distortion to uncover potentially visionthreatening pathology. This can be achieved through a directed history and examination.

\section{Objective}

The aim of this article is to provide a guide to clarifying complaints of visual distortions, outlining the common ocular causes, with a focus on macular pathologies.

\section{Discussion}

Targeted clues in the cause of visual distortions can be obtained through a directed history. Simple office-based examination techniques such as visual acuity, the use of Amsler's grid and fundoscopy are useful to identify pathology responsible for visual distortions. A basic assessment and knowledge of macular pathologies can assist GPs' appropriate assessment, treatment and referral of patients who present with visual distortions.
VISUAL DISTORTION is a common presentation in general practice. Patients can find it challenging to convey the subjective nature of their visual distortions and often describe the changes as 'blurred vision' or 'vision loss'. Metamorphopsia, micropsia, macropsia, scotomas and paracentral scotomas are all symptoms of visual function disturbance described in various macular disorders. ${ }^{1}$ These visual symptoms can often herald or precede an underlying maculopathy. Visual distortion secondary to macular haemorrhage can lead to potentially irreversible loss of vision if not treated promptly. Visual distortion secondary to macular oedema in central retinal vein occlusion (CRVO) could indicate malignant hypertension, leading to stroke and other end-organ damage if left undiagnosed. Thus, visual distortions should be clarified and not overlooked. It is through a comprehensive assessment that a general practitioner (GP) can identify red flags to potentially sight-threatening or life-threatening conditions and refer appropriately. This article focuses on visual distortions secondary to maculopathies and other ocular causes; however, it is important to consider neurogenic causes in assessment.

\section{History}

Obtaining a detailed history is important to elicit potential causes of visual distortions. A patient's demographic,

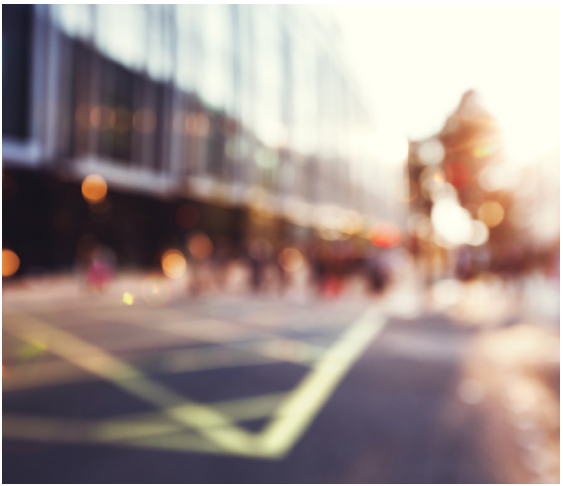

including their age, sex and race, should be noted. A systemic history is important to highlight any co-existing risk factors, such as diabetes, hypertension and hypercholesterolaemia. A personal and family ocular history should be obtained. A social history, inclusive of smoking history, is also relevant. A detailed medication history is important as numerous medications are associated with visual phenomena. Vasodilators such as erectile dysfunction drugs (eg sildenafil) may result in cyanopsia, a distinctive bluish tinge in vision. Vasodilators such as beta blockers and anti-anginal medications are known to cause phenomena such as shimmering, halos or scintillations. Systemic corticosteroids are associated with central serous chorioretinopathy (CSCR) and resultant visual distortions.

\section{Nature of visual distortion}

Distortions in vision can be described in terms of shape (metamorphopsia), size (micropsia or macropsia) and colour (dyschromatopsia), and possible aetiologies can be localised to the orbit itself or to the occipital cortex. Metamorphopsia is defined as a deviation of either vertical or horizontal lines in central vision as described by the patient, and commonly indicates macular pathology. ${ }^{1}$ Patients may complain of typically straight objects, such as doorways or window frames, looking bent or twisted, or simply objects 
'changing shape'. Distortions can manifest as objects appearing disproportionately large (macropsia) or small (micropsia). Dyschromatopsia or colour aberrations can also be implicated, but generally indicate optic nerve pathology. Hemeralopia (day blindness) or nyctalopia (night blindness) can indicate retinal dystrophies. It is important to elicit the location of the visual distortion. Is it a sectoral field change suggestive of detachment, optic neuropathy or retinal vascular disease? Or is it a central or paracentral abnormality, seen in maculopathies or glaucomatous disease? Has the patient's ability to read deteriorated because of sections of the page being missing or are they having issues with face perception due to a darkened central scotoma? Determining whether the visual disturbance is present in one eye (monocular) or both eyes (binocular) can also aid in localising the pathology. A monocular disturbance suggests that the lesion is anterior to the optic chiasm (eg retina, optic nerve, cornea); in contrast, binocular disturbances are more likely to be neurological. Associated visual symptoms such as photopsia, floaters and transient scintillating colours may indicate aetiologies such as tears, detachments and ocular migraines, respectively.

\section{Onset, duration and evolution of symptoms}

A transient visual obscuration such as that experienced in embolic phenomena (eg amaurosis fugax) is likely to require more urgent evaluation than a central visual distortion of 12 months' duration. Onset, duration and evolution of symptoms helps triage the urgency of referral. A static, central distortion of longer duration can be suggestive of maculopathies such as chronic, dry, age-related macular degeneration (AMD), macular hole, epiretinal membrane (ERM) and diabetic macular oedema (DMO). Conversely, a rapidly worsening central distortion can be indicative of wet AMD with choroidal neovascular membrane (CNVM) or CRVO with insipient cystoid macular oedema (CMO). Associated history of previous visual distortions in a young middle-aged male can be strongly suggestive of CSCR. A history of previous sudden visual loss, in particular sectoral field changes, months or years prior to central distortion development can be a sign of retinal vein occlusion with subsequent CMO. ${ }^{1}$

\section{Associated symptoms}

Any associated symptoms should be noted. Weakness or numbness on one side of the body, diplopia, slurred speech, headaches, difficulty swallowing, word-finding problems and imbalance should be evaluated to rule out a neurological cause of visual distortions.

\section{Examination}

\section{Vital and other signs}

A patient's vital signs should be taken. Systemic hypertension is particularly important and may manifest as hypertensive retinopathy/neuropathy and retinal vein occlusion (RVO), leading to macular oedema. It may also be pertinent to check blood sugar levels or to conduct cardiovascular and/or neurological examinations depending on the nature of the presentation.

\section{Visual acuity}

Visual acuity testing should be performed using a Snellen chart and with appropriate refractive correction (ie the patient should wear their glasses if that is usual), or using a pinhole. This can be performed using a handheld chart or conventional charts positioned at three and six metres' distance from the patient. If the patient is unable to see any letters, evaluate whether the patient can count fingers, observe hand movements or simply perceive light. Visual distortions are often coupled with impaired visual acuity.

\section{Intraocular pressure}

Various forms of tonometry exist to measure intraocular pressure. Rebound tonometry, such as iCare, is the most prevalent portable device and uses a small plastic-tipped probe that bounces gently against the cornea to obtain a reading.

\section{Pupils}

Pupils should be examined for size and their direct and consensual responses. The 'swinging light test' can be employed to test for a relative afferent pupil defect (RAPD), whereby a dilatory response is elicited because of a reduction in afferent impulses from the optic nerve. An RAPD is generally observed in optic nerve disease. ${ }^{2}$

\section{Visual fields}

Visual fields to confrontation can help define whether the pathology is neurological or retinal. Sitting directly across from the patient, the GP occludes one eye at a time, mirroring the patient. The patient, looking directly ahead, should indicate when a moving target (usually the GP's finger) is seen being brought in from the periphery in all four quadrants. The patient's visual field is compared with the GP's to assess for any abnormalities.

\section{Colour vision}

Colour vision testing using Ishihara plates helps differentiate neurogenic from non-neurogenic vision changes. Acquired dyschromatopsia can be seen with lesions of the optic nerve, retina or the visual cortex. Cerebral dyschromatopsia caused by lesions at the occipital-temporal lobe junction is usually accompanied by other focal neurology, including homonymous visual field defects. ${ }^{1}$

\section{Amsler grid}

The Amsler grid was the first functional test proposed to evaluate visual distortions (Figure 1A). ${ }^{1}$ It has application in general practice to discover the presence and location of defects in the central field of vision and can also be used for home monitoring by patients. Magnetised Amsler grids can be ordered from the Macular Disease Foundation Australia website and are accessible on various device applications. The Amsler grid allows for simple and rapid qualitative evaluation of alterations of visual function in the central 10 degrees around a fixation point. It consists of a black or white card on which vertical and horizontal parallel lines are drawn, subdivided every $5 \mathrm{~mm}$ to form a $10 \mathrm{~cm}$ square. The Amsler grid can be used with patients using the following instructions:

- wear your reading glasses and hold the grid at reading distance (approximately $28-30 \mathrm{~cm}$ ) 
- cover one eye

- focus on the black dot in the centre of the grid without moving your eye

- comment on whether there are any broken, wavy, distorted or missing areas ${ }^{1}$

- repeat the process with the other eye. Abnormalities can include the absence of a central fixation point (central scotoma), inability to perceive outer areas of the grid (arcuate scotoma), an area of the grid that is missing (paracentral scotoma), or distortions in which the lines appear curvy or wavy (metamorphopsia; Figures 1B, 1C), which can be further described as lines 'bending' inwards (micropsia) or outwards (macropsia). ${ }^{3}$

\section{Fundoscopy}

Fundoscopy is performed with the lights off or dimmed and the patient in a seated position. Dilate the patient with tropicamide $1 \%$ in each eye if pupil examination is normal and acute angle closure and trauma is not suspected. Dilation may take 15 minutes. Instruct the patient to fixate on a precise area, such as the corner of the room. While holding the ophthalmoscope, the GP should examine the patient's left eye with their own left eye and the patient's right eye with their own right eye. The presence of a red reflex should be assessed, and the optic disc can be subsequently located by following the blood vessels. The retinal vessels can be assessed and the macula identified by looking temporally to the optic disc. Fundoscopic abnormalities are summarised in Table 1. The PanOptic Ophthalmoscope is particularly useful in general practice as it allows a fundal view that is five times greater than that seen with a standard ophthalmoscope in an undilated eye.

\section{Differential diagnosis}

The most common macular diseases characterised functionally by visual distortions are included in Table 2. Diagnosis can be made using imaging modalities such as optical coherence tomography and various fundus photography techniques.

\section{Referral}

Acute visual distortions or sudden deterioration of vision warrant urgent referral for ophthalmological evaluation. These could represent maculopathies such as wet AMD with CNVM or potentially $\mathrm{CRVO}$ with $\mathrm{CMO}$, requiring further investigation and management. More indolent, progressive visual distortions may indicate conditions such as macular hole, epiretinal membrane, diabetic macular oedema or worsening dry AMD, requiring semi-urgent evaluation. It is important that GPs employ their clinical acumen in the referral process. For example, if there is concomitant vital sign instability or focal neurologic symptoms in conjunction with visual distortions, referral to an emergency department may be warranted for a holistic work-up. If there is uncertainty about the aetiology

\section{Table 1. Fundoscopic abnormalities}

\begin{tabular}{ll}
\hline Red reflex & $\begin{array}{l}\text { Reduced red reflex in corneal scarring, cataract, vitreous haemorrhage, } \\
\text { asteroid hyalosis }\end{array}$ \\
\hline Optic disc & $\begin{array}{l}\text { Pallor, swelling (papilloedema), haemorrhage, gross cupping, } \\
\text { new disc vessels }\end{array}$ \\
\hline Vessels & $\begin{array}{l}\text { Arteriovenous nipping, venous congestion and beading, emboli, } \\
\text { microaneurysms, haemorrhages, exudate, cotton wool spots, } \\
\text { new retinal vessels }\end{array}$ \\
\hline Macula & Drusen, exudates, haemorrhage, pigmentary changes \\
\hline
\end{tabular}
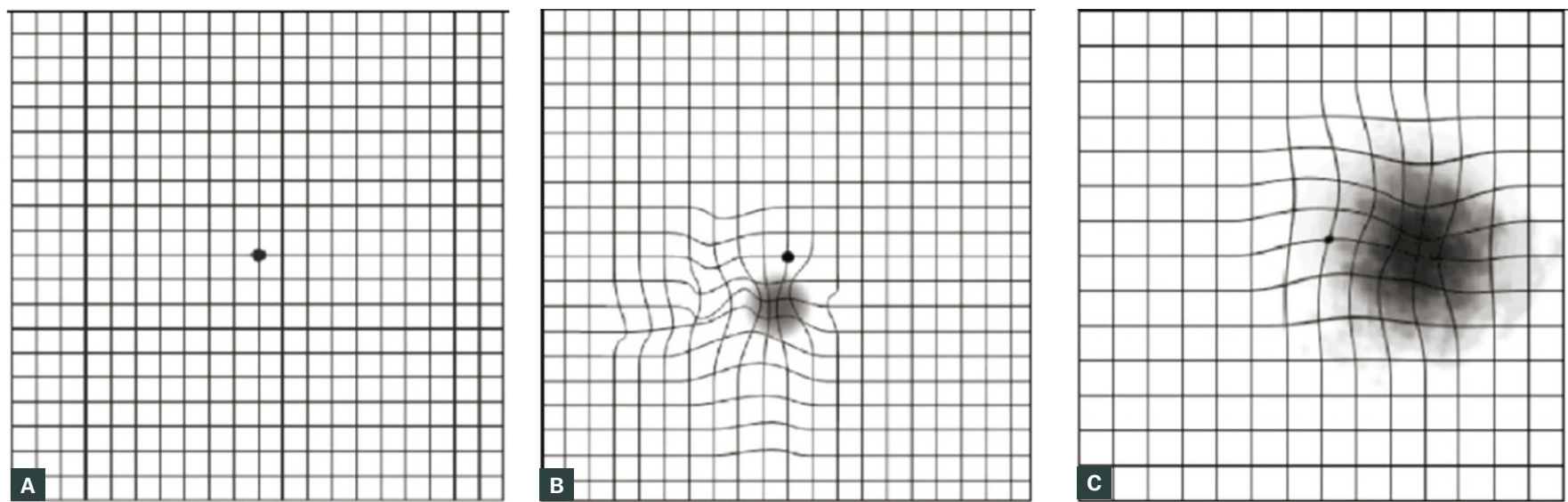

Figure 1. Amsler grid examples

A. Normal Amsler grid; B. Small scotoma below central fixation with surrounding metamorphopsia; c. Large scotoma encroaching central fixation with some metamorphopsia ${ }^{4}$

Figure reproduced from Broadway DC. Visual field testing for glaucoma - A practical guide. Community Eye Health 2012:25(79-80):66-70. Licence at https://creativecommons.org/licenses/by-nc/3.0/au/ 
in a general practice setting, where diagnostics are limited, it is prudent to refer for further evaluation by an optometrist or ophthalmologist.

\section{Key points}

- Visual distortions can indicate a scope of macular pathologies, from benign to potentially sight-threatening.

- A directed history and examination using office-based techniques including visual acuity, Amsler grid and fundoscopy are helpful in the initial assessment.

- Urgency of ophthalmological evaluation is based on the nature of the presentation.

\section{Authors}

Corey Rowland MBBS, Clinical Fellow, City Eye Centre, Brisbane, Qld

Lawrence R Lee MBBS, FRANZCO, FRACS, Associate Professor, City Eye Centre, University of Queensland; Royal Brisbane \& Women's Hospital, Brisbane, Qld. eye@cityeye.com.au

Competing interests: None.

Funding: None.

Provenance and peer review: Commissioned, externally reviewed.

\section{References}

1. Midena E, Vujosevic S. Metamorphopsia: An overlooked visual symptom. Ophthalmic Res 2016;55(1):26-36. doi: 10.1159/000441033.

2. Rahman S, Grewal DS, Bhat P, Fallor M, Volpe NJ, Mirza R. Relative afferent pupillary defect detected in asymmetric macular disease using an automated binocular pupillometer. Invest Ophthalmol Vis Sci 2014;55(13):1185.

3. Pandey AN, Raina A, Sharma PD. A study on Amsler's Grid in acquired macular disorders. Ophthalmology Research: An International Journal 2016;6(3):1-7. doi: 10.9734/OR/2016/28850.

4. Broadway DC. Visual field testing for glaucoma - A practical guide. Community Eye Health 2012:25(79-80):66-70.

5. Al-Zamil WM, Yassin SA. Recent developments in age-related macular degeneration: A review. Clin Interv Aging 2017;12:1313-30. doi: 10.2147/CIA. S143508.

6. Smith W, Assink J, Klein R, et al. Risk factors for age-related macular degeneration: Pooled findings from three continents. Ophthalmology 2001;108(4):697-704.

7. Chakravarthy U, Wong TY, Fletcher A, et al. Clinical risk factors for age-related macular degeneration: A systematic review and metaanalysis. BMC Ophthalmol 2010;13;10:31. doi: 10.1186/1471-2415-10-31.

8. Parekh N, Voland RP, Moeller SM, et al. Association between dietary fat intake and agerelated macular degeneration in the Carotenoids in Age-Related Eye Disease Study (CAREDS): An ancillary study of the women's health initiative. Arch Ophthalmol 2009;127(11):1483-93. doi: 10.1001/archophthalmol.2009.130.
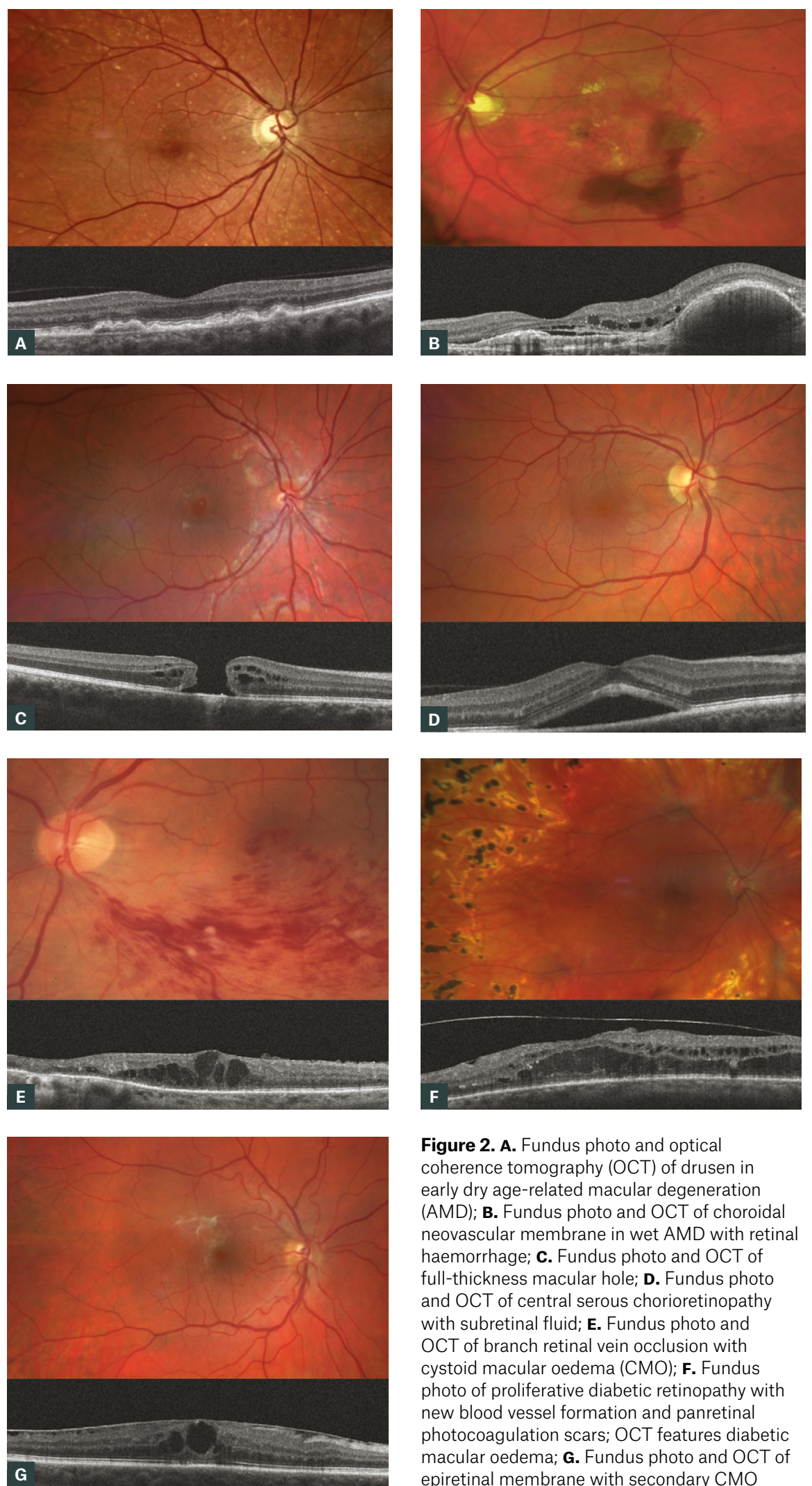

Figure 2. A. Fundus photo and optical coherence tomography (OCT) of drusen in early dry age-related macular degeneration (AMD); B. Fundus photo and OCT of choroidal neovascular membrane in wet AMD with retinal haemorrhage; c. Fundus photo and OCT of full-thickness macular hole; D. Fundus photo and OCT of central serous chorioretinopathy with subretinal fluid; E. Fundus photo and OCT of branch retinal vein occlusion with cystoid macular oedema (CMO); F. Fundus photo of proliferative diabetic retinopathy with new blood vessel formation and panretinal photocoagulation scars; OCT features diabetic macular oedema; G. Fundus photo and OCT of epiretinal membrane with secondary $\mathrm{CMO}$ 
Table 2. Common maculopathies causing visual distortions

\begin{tabular}{|c|c|c|c|c|c|c|}
\hline Maculopathy & $\begin{array}{l}\text { Age-related macular } \\
\text { degeneration (AMD) }\end{array}$ & Macular holes & $\begin{array}{l}\text { Central serous } \\
\text { chorioretinopathy }\end{array}$ & $\begin{array}{l}\text { Retinal vein } \\
\text { occlusion (RVO) } \\
\text { with cystoid } \\
\text { macular oedema }\end{array}$ & $\begin{array}{l}\text { Diabetic } \\
\text { retinopathy with } \\
\text { diabetic macular } \\
\text { oedema }\end{array}$ & $\begin{array}{l}\text { Vitreomacular } \\
\text { interface disorders }\end{array}$ \\
\hline Definition & $\begin{array}{l}\text { Acquired disease } \\
\text { characterised by } \\
\text { neurodegeneration of the } \\
\text { photoreceptor-retinal } \\
\text { pigment epithelial } \\
\text { complex }^{5}\end{array}$ & $\begin{array}{l}\text { A retinal break } \\
\text { commonly } \\
\text { involving the } \\
\text { fovea }^{12}\end{array}$ & $\begin{array}{l}\text { Characterised by } \\
\text { accumulation of } \\
\text { subretinal fluid, } \\
\text { commonly under the } \\
\text { macula }^{15}\end{array}$ & $\begin{array}{l}\text { Retinal vein } \\
\text { occlusive disease } \\
\text { leading to } \\
\text { complications of } \\
\text { interrupted blood } \\
\text { flow including } \\
\text { macular swelling }\end{array}$ & $\begin{array}{l}\text { Diabetic disease } \\
\text { leading to } \\
\text { accumulation of fluid } \\
\text { in the macula }{ }^{19}\end{array}$ & $\begin{array}{l}\text { Vitreomacular } \\
\text { interface } \\
\text { abnormalities } \\
\text { inclusive of } \\
\text { adhesions, traction } \\
\text { and membranes }{ }^{21}\end{array}$ \\
\hline Types & $\begin{array}{l}\text { - Dry (non-exudative) } \\
\text { - Wet (exudative) }\end{array}$ & $\begin{array}{l}\text { - Full-thickness } \\
\text { - Partial-thickness } \\
\text { (lamellar holes) }\end{array}$ & $\begin{array}{l}\text { - Acute } \\
\text { - Chronic }\end{array}$ & $\begin{array}{l}\text { Branch retinal } \\
\text { vein occlusion } \\
\text { - Central retinal } \\
\text { vein occlusion }\end{array}$ & $\begin{array}{l}\text { - Non-proliferative } \\
\text { diabetic } \\
\text { retinopathy } \\
\text { - Proliferative } \\
\text { diabetic } \\
\text { retinopathy }\end{array}$ & $\begin{array}{ll}\text { - } & \text { Vitreomacular } \\
\text { traction (VMT) } \\
\text { - } & \text { Epiretinal } \\
& \text { membrane (ERM) }\end{array}$ \\
\hline Risk factors & $\begin{array}{l}\text { - Increasing age } \\
\text { - Ethnicity } \\
\text { - Genetics } \\
\text { - Smoking } \\
\text { - High intake of saturated } \\
\text { and trans fats and } \\
\text { omega-6 fatty acids } \\
\text { - Abdominal obesity } \\
\text { - Hyperlipidaemia } \\
\text { - Hyperopia } \\
\text { - Light iris colour } \\
\text { - Cardiovascular disease } \\
\text { - Hormonal status } \\
\text { - Alcohol use } \\
\text { - Vitamin B and D status } \\
\text { - Elevated C-reactive } \\
\text { protein } 6-8\end{array}$ & $\begin{array}{l}\text { - Age } \\
\text { - Female sex } \\
\text { - Myopia } \\
\text { - Trauma } \\
\text { - Ocular } \\
\text { inflammation }{ }^{13}\end{array}$ & $\begin{array}{l}\text { - Age } \\
\text { - Male sex } \\
\text { - Corticosteroid } \\
\text { exposure } \\
\text { - Phosphodiesterase } \\
\text { inhibitor use } \\
\text { - Obstructive sleep } \\
\text { apnoea } \\
\text { - 'Type A' personality } \\
\text { traits }^{16}\end{array}$ & $\begin{array}{l}\text { - } \text { Systemic arterial } \\
\text { hypertension } \\
\text { - Atherosclerosis } \\
\text { - Diabetes } \\
\text { - Thrombophilia } \\
\text { - Glaucoma } \\
\text { - Sleep apnoea } \\
\text { - Homocystinuria }{ }^{17}\end{array}$ & 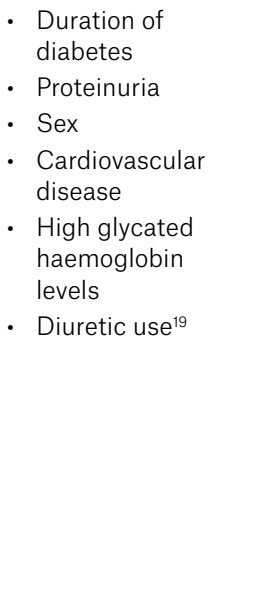 & $\begin{array}{l}\text { - Age } \\
\text { - Retinal vascular } \\
\text { disease } \\
\text { - Diabetes } \\
\text { - Trauma } \\
\text { - Inflammatory } \\
\text { conditions } \\
\text { - Tumours } \\
\text { - Retinal } \\
\text { dystrophies }\end{array}$ \\
\hline Symptoms & $\begin{array}{l}\text { - Reduced vision } \\
\text { - Visual distortions }\end{array}$ & $\begin{array}{l}\text { - } \text { Reduced vision } \\
\text { - Visual distortions }\end{array}$ & $\begin{array}{l}\text { - Reduced vision } \\
\text { - Visual distortions }\end{array}$ & $\begin{array}{l}\text { - Reduced vision } \\
\text { - Visual distortions }\end{array}$ & $\begin{array}{l}\text { - Reduced vision } \\
\text { - Visual distortions }\end{array}$ & $\begin{array}{l}\text { - Reduced vision } \\
\text { - Visual distortions }\end{array}$ \\
\hline $\begin{array}{l}\text { Clinical } \\
\text { features }\end{array}$ & $\begin{array}{l}\text { Dry AMD: Drusen and } \\
\text { geographical atrophy } \\
\text { in advanced disease } \\
\text { (Figure 2A) } \\
\text { - Wet AMD: Choroidal } \\
\text { neovascular membrane } \\
\text { and PED (Figure } 2 \mathrm{~B} \text { ) }\end{array}$ & $\begin{array}{l}\text { Well-defined } \\
\text { round or } \\
\text { oval lesion in } \\
\text { the macula } \\
\text { (Figure } 2 \mathrm{C} \text { ) }\end{array}$ & $\begin{array}{l}\text { Well-demarcated } \\
\text { round or oval- } \\
\text { shaped area of } \\
\text { neurosensory } \\
\text { detachment with } \\
\text { or without serous } \\
\text { PED (Figure 2D) }\end{array}$ & $\begin{array}{l}\text { - Vascular } \\
\text { tortuosity } \\
\text { - } \text { Retinal } \\
\text { haemorrhages } \\
\text { - Cotton wool } \\
\text { spots } \\
\text { - Optic nerve } \\
\text { oedema } \\
\text { - } \text { Macular oedema } \\
\text { (Figure 2E) }\end{array}$ & $\begin{array}{l}\text { - Macular } \\
\text { thickening } \\
\text { - Exudates and } \\
\text { cystoid changes } \\
\text { - Microaneurysms } \\
\text { - Haemorrhage } \\
\text { - Hard exudates } \\
\text { - Retinal } \\
\text { neovascularisation } \\
\text { (Figure 2F) }\end{array}$ & $\begin{array}{l}\text { VMT: Distortion } \\
\text { of the fovea, } \\
\text { blunted foveal } \\
\text { reflex, cystic } \\
\text { macular changes, } \\
\text { subretinal fluid } \\
\text { - ERM: Reflective } \\
\text { sheen over retina, } \\
\text { wrinkling of } \\
\text { retinal surface } \\
\text { (Figure } 2 \mathrm{G} \text { ) }\end{array}$ \\
\hline Treatment & $\begin{array}{l}\text { Dry AMD: Preventative } \\
\text { strategies; smoking } \\
\text { prevention; daily dose } \\
\text { of vitamin C, vitamin E, } \\
\text { lutein, zeaxanthin, zinc } \\
\text { oxide and cupric oxide } \\
\text { - Wet AMD: Intravitreal } \\
\text { anti-VEGF injections, } \\
\text { such as ranibizumab, } \\
\text { bevacizumab and } \\
\text { aflibercept }{ }^{10,11}\end{array}$ & $\begin{array}{l}\text { Surgical repair } \\
\text { with vitrectomy } \\
\text { with or without } \\
\text { internal limiting } \\
\text { membrane } \\
\text { peel and gas } \\
\text { tamponade; } \\
\text { post-operative } \\
\text { posturing } \\
\text { required }^{14}\end{array}$ & $\begin{array}{l}\text { Spontaneous } \\
\text { resolution of fluid } \\
\text { by three months; } \\
\text { potential therapies } \\
\text { include focal laser } \\
\text { photocoagulation, } \\
\text { photodynamic } \\
\text { therapy and } \\
\text { intravitreal } \\
\text { anti-VEGF } \\
\text { medications }^{16}\end{array}$ & $\begin{array}{l}\text { Therapies } \\
\text { targeted at } \\
\text { complications of } \\
\text { RVO; intravitreal } \\
\text { anti-VEGF } \\
\text { therapy, grid laser } \\
\text { and intravitreal } \\
\text { steroids }^{18}\end{array}$ & $\begin{array}{l}\text { - Intravitreal } \\
\text { injections, laser } \\
\text { photocoagulation } \\
\text { and vitreous } \\
\text { surgery }^{20}\end{array}$ & $\begin{array}{l}\text { VMT: Paras } \\
\text { plana vitrectomy; } \\
\text { pharmacologic } \\
\text { vitreolysis with } \\
\text { ocriplasmin } \\
\text { - ERM: Pars plana } \\
\text { vitrectomy with } \\
\text { membrane peel }{ }^{21}\end{array}$ \\
\hline
\end{tabular}

PED, pigment epithelial detachment; VEGF; vascular endothelial growth factor 
9. Age-Related Eye Disease Study 2 Research Group. Lutein + zeaxanthin and omega-3 fatty acids for age-related macular degeneration: The Age-Related Eye Disease Study 2 (AREDS2) randomized clinical trial. JAMA 2013;309(19):2005-15. doi: 10.1001/ jama.2013.4997.

10. Mantel I. Optimizing the anti-VEGF treatment strategy for neovascular age-related macular degeneration: From clinical trials to real-life requirements. Transl Vis Sci Technol 2015;4(3):6.

11. Park DH, Sun HJ, Lee SJ. A comparison of responses to intravitreal bevacizumab, ranibizumab, or aflibercept injections for neovascular age-related macular degeneration. Int Ophthalmol 2017;37(5):1205-14. doi: 10.1007/ s10792-016-0391-4.

12. Zhao PP, Wang S, Liu N, Shu ZM, Zhao JS. A review of surgical outcomes and advances for macular holes. J Ophthalmol 2018;2018:7389412. doi: 10.1155/2018/7389412.

13. La Cour M, Friis J. Macular holes: Classification, epidemiology, natural history and treatment. Acta Ophthalmol Scand 2002;80(6):579-87.

14. Dhawahir-Scala FE, Maino A, Saha K, Mokashi AA, McLauchlan R, Charles S. To posture or not to posture after macular hole surgery. Retina 2008;28(1):60-65. doi: 10.1097/ IAE.0b013e31813c68a2.

15. Wang $M$, Munch IC, Hasler PW, Prünte $C$, Larsen M. Central serous chorioretinopathy. Acta Ophthalmol 2008;86:126-45.

16. Ross A, Ross AH, Mohamed Q. Review and update of central serous chorioretinopathy. Curr Opin Ophthalmol 2011;22(3):166-73. doi: 10.1097/ ICU.0b013e3283459826.

17. Rogers SL, Mclntosh RL, Lim L, et al. Natural history of branch retinal vein occlusion: An evidence-based systematic review. Ophthalmology 2010;117(6):1094-101.e5. doi: 10.1016/j. ophtha.2010.01.058.
18. Ip $\mathrm{M}$, Hendrick $A$. Retinal vein occlusion review. Asia Pac J Ophthalmol (Phila) 2018;7(1):40-45. doi: 10.22608/APO.2017442.

19. Gundogan F, Yolcu U, Akay F, Ilhan A, Ozge G, Uzun S. Diabetic macular edema. Pak J Med Sci 2016;32(2):505-10. doi: 10.12669/pjms.322.8496.

20. Wang W, Lo ACY. Diabetic retinopathy: Pathophysiology and treatments. Int J Mol Sci 2018;19(6). pii: E1816. doi: 10.3390/ijms19061816.

21. Levison $A L$, Kaise PK. Vitreomacular interface disease: Diagnosis and management. Taiwan J Ophthalmol 2014;4(2):63-68. doi: 10.1016/j. tjo.2013.12.001. 